\title{
Trump, Recent Court Cases and the 2020 Presidential Election
}

\author{
Stuart S. Malawer*
}

In this essay, the author will discuss recent United States Supreme Court cases as well as international trade cases decided this year by the specialized international trade courts in the United States. Let me then discuss recent U.S. trade action concerning China and put this in the context of President Trump's generalized approach to China and international trade. This article will conclude with a few observations pertaining to the upcoming presidential election in the United States. The. Supreme Court recently ruled on two highly politicized and historic cases on executive power. What has been almost totally overlooked is an international trade decision by a three-judge panel of the United States Court of International Trade. That case and earlier trade cases indicate the start of a multifaceted attempt to restrict the president's trade policies. Either the 2020 presidential election will put a stop to President Trump's reliance on national security to establish disastrous trade policies, or the country will be in this mess for years to come.

* Distinguished Service Professor of Law and International Trade at George Mason's University's Schar School of Policy and Government. J.D. (Cornell), M.A./Ph.D. (UPenn), Diploma (The Hague Academy of International Law). Additional legal studies at Harvard Law School and Oxford University (St. Peter's College). He is the author of Trump and Trade-Policy and LaW (HeinOnlne 2020), Global Trade and International Law (Hein 2012), U.S. National Security Law (Hein 2009) and WTO Law, Litigation \& Policy (Hein 2007). Dr. Malawer is a member of the bars of the State of New York, the Commonwealth of Virginia and of the United States Court of International Trade. He is a recent gubernatorial appointee to the new Advisory Committee on International Trade (Virginia Economic Development Partnership). Dr. Malawer has been a delegate on various Virginia gubernatorial trade missions to Asia. He is a former Chairman of the International Practice Section of the Virginia State Bar. Social Science Research Network Id. 1073612. The author may be contacted at: StuartMalawer@msn.com; http://www. GlobalTradeRelations.net; http://www.US-Global-Law.net/Address: 3351 Fairfax Dr., MS 3B1, Arlington, Virginia 22201 USA.

All the websites cited in this paper were last visited on August 16, 2020. The paper was completed as of that date. 
Keywords: Section 232, National Security, Trade and National Emergencies, US Court of International Trade, 2020 Presidential Elections, John Bolton, TikTok, WeChat, CFIUS, Huawei.

\section{Recent Supreme Court Cases and International Trade Cases}

The US Supreme Court recently ruled on two highly politicized and historic cases on executive power. ${ }^{1}$ Observers have commented that these decisions have restricted excessive claims of executive authority. ${ }^{2}$ However, these same observers have overlooked a United States Court of International Trade decision made at about the same time that limits presidential authority on trade issues. These cases ought to be placed in the context of even more recent restrictions President Trump has placed on Chinese trade and investment activities. Additionally, those restrictions should be seen in the broader context of President Trump's generalized hatred of laws and rules, both domestic and international, which is being especially accentuated in the run-up to the presidential election in November 2020.

The two Supreme Court cases proclaimed that presidents are neither above the law nor immune from congressional or state criminal subpoenas. These 7-2 decisions were surprisingly written by Chief Justice John Roberts and joined by the liberal wing of the Court. Similarly surprisingly, Chief Justice Roberts was joined by two of President Trump's conservative appointees, Justices Neil Gorsuch and Brett Kavanaugh. ${ }^{3}$

What has been almost totally overlooked is an international trade decision, released at about the same time as the Supreme Court's decisions, made by a three-judge panel of the United States Court of International Trade concerning the import of Turkish steel and Section 232 of the Trade Expansion Act of 1962.

In this case-decided July 14, 2020 - the United States Court of International Trade declared that the Trump administration's additional tariffs on the import of Turkish steel under Section 232 (national security) were invalid. ${ }^{5}$ Their imposition failed to fall within the statutory period of action. The larger story is that this is the first time a determination has been made that there was a procedural violation under Section 232 and that the tariffs were invalid.

This case specifically restricted the imposition of tariffs when the president 
relied upon national security as a rationale for imposing tariffs. This is important, as other court cases are moving forward, in addition to Congress's attempt to reclaim its trade authority. This decision could very well indicate the start of a multifaceted attempt to restrict the president's trade policies in areas beyond tariffs, for example, when he relies on one of the many statutes that give him extraordinary trade powers during national emergencies.

To me, this judicial development amounts to a small but significant advance in the growing attack on the president's use of national security as a basis for tariffs and other trade actions, as well as a possible violation of the doctrine of separation of powers. The court stated forcefully that a tariff cannot be irrational-without bearing on national security.

The court cited the 2019 circuit court case concerning the action taken by the steel importers association (American Institute for International Steel) ${ }^{6}$ attacking the administration's tariffs on steel imports from China, which also raised concerns regarding the use of national security.

Here are a few more details about the Turkish steel imports from the case the Court of International Trade decided in July. In Transpacific Steel v. United States (United States Court of International Trade), a three-judge panel ruled (July 14, 2020) that Trump's increase in Section 232 tariffs on steel imports from Turkey violated statutory procedures. ${ }^{7}$ The court held that: "[s]ingling out steel products from Turkey is not a rational means of addressing (national security) concerns." ${ }^{\prime 8}$ Thus, the court articulated a rational test that the tariffs must be rational with regard to national security concerns:

\footnotetext{
National security is dependent on sensitive and ever-changing dynamics; the temporal restrictions on the President's power to take action pursuant to a report and recommendation by the Secretary is not a mere directory guideline, but a restriction that requires strict adherence. To require adherence to the statutory scheme does not amount to a sanction, but simply ensures that the deadlines are given meaning and that the President is acting on up-to-date national security guidance.
}

Noting the leading case often cited by the government in upholding the legality of Section 232 actions, the court stated: "In Federal Energy Administration v. Algonquin $S N G$, Inc., the Court stressed the importance of the procedural safeguards in holding that Section 232 was not an impermissible delegation of congressional 
authority over imports." ${ }^{10}$ The trade court went on to consider national security. While it viewed national security as a legitimate purpose, it concluded that there was no persuasive evidence to support a rational connection to the imposition of additional tariffs. The court declared: "Unlike the determination made by the Court in Trump v. Hawaii, ${ }^{11}$ there is no "persuasive evidence" here to support that the President's proclamation "has a legitimate grounding in national security concerns." ${ }^{\text {,2 }}$ The court concluded:

Section 232 does not ban the President from addressing concerns by focusing on particular exporters, but the decision to increase the tariffs on imported steel products from Turkey, and Turkey alone, without any justification, is arbitrary and irrational. ${ }^{13}$

Earlier in the Supreme Court term, on June 22, 2020, the Supreme Court denied certiorari of an appeal from the US Court of Appeals for the Federal Circuit in the litigation brought by the American Institute for International Steel (AIIS) ${ }^{14}$ in which it alleged the unconstitutionality of Section 232 tariffs as a violation of the separation of powers because Congress's delegation of authority to the president was too broad. Both the Circuit Court and the United States Court of International Trade held against the steel importers, saying the earlier Supreme Court case Algonquin $^{15}$ was controlling precedent and still good law. That case upheld the constitutionality of the presidential imposition of import license fees for national security reasons under Section 232.

In the United States Court of International Trade, the plaintiff (AIIS) filed a motion for summary judgment. The government moved for judgment on the pleadings. The Court held that the Supreme Court's decision in Algonquin required rejection of the constitutional challenge and granted the government's motion. ${ }^{16}$ However, one judge did consider that newer events might be considered in violation of the Section 232 delegation of authority to the president. ${ }^{17}$

\section{President Trump's Recent China Actions (TikTok and WeChat) \& New Tariffs (Canada)}

With President Trump's reelection chances declining daily, he has returned to 
two of his favorite topics: demonizing China and threatening new tariffs. Trump is now threatening to ban $\operatorname{TikTok}^{18}$ and WeChat ${ }^{19}$ in the US. These actions against Chinese owned websites are intended to address the issue of data security and mobile communications. They relate to a very broad range of possible transactions. $\mathrm{He}$ is doing this while relying on two pieces of broad international economic legislation, the International Emergency Economic Powers $\mathrm{Act}^{20}$ and the National Emergencies Act, ${ }^{21}$ that allow presidents to take actions for defending national security (risks from outside of the US) and during national emergencies.

President Trump has also threatened, once again, to delist Chinese firms from public markets, requiring them to comply with new federal securities regulations regarding corporate audits. ${ }^{22}$ Of course, he continues to utilize the Committee on Foreign Investment in the United States (CFIUS) to hamper new Chinese investments in the US, for example, by Huawei, which is also investigating TikTok. All of this is in addition to a large number of tariffs, export controls and various other sanctions (for example, Section 301 retaliation) imposed on China and its officials. ${ }^{23}$

President Trump is also reimposing tariffs on aluminum imports from Canada in apparent violation of the new regional trade agreement with Canada and Mexico. These tariffs are being imposed under the Section 232 national security rationale.

\title{
3. President Trump's Threats and Disregard of Law
}

I wrote earlier in 2020 about President Trump's approach to global trade relations:

\begin{abstract}
One can draw a straight line from Donald Trump's ruthless mode of operating in the contentious world of New York real estate to his operations on the world stage today.... President Trump's ruthless approach has been employed in a range of multilateral trade relations. ... It has also gone beyond bilateral trade disputes by attacking the legitimacy of the WTO's judicial system and, indeed, the WTO itself. ${ }^{24}$
\end{abstract}

Subsequent to that assessment, in the summer of 2020, the former national security adviser to the president, John Bolton, wrote bluntly in his memoir ${ }^{25}$ an even more 
brutal assessment of President Trump's approach to trade and China, in particular:

Decision-making on trade issues under Trump, however, was painful. ... [Quoting President Trump] "The Chinese don't give a sh-t about us: they are cold-blooded killers [on trade]." I could see the trade issues would be a wild ride. ${ }^{26}$

Trump approached trade and trade deficits as if reading a corporate balance sheet: trade deficits meant we were losing, and trade surpluses meant we were winning. ... [I] scoffed at such arguments.

Bolton added his own views on China and the WTO, which were gladly accepted by the president:

Bringing China into the World Trade Organization in 2001 was the apotheosis of this assessment [of China as a responsible stakeholder]. ... America has been slow to awaken to basic mistakes made decades ago. ${ }^{28}$

Both Bolton and President Trump contend that the WTO undermines the US sovereignty. However, as one observer recently stated, "The notion that the WTO undermines U.S. sovereignty is a straw man. ${ }^{29}$ To me, the argument of undermining the US sovereignty is a rhetorical cover for highly politicized and unilateral trade actions by the Trump administration, reflecting the administration's total disdain and disregard of international rules and the judicial system of which the US was the principal architect in the post-World War II era. This system reflected America's fundamental belief in the rule of law and its impartial adjudication on both the domestic and international levels.

\section{Concluding Observations: Where does the US stand now?}

During the last few weeks of the presidential race, President Trump used trade and related restrictions under his authority to impose them for national security or emergencies reasons. To me, it is not abating. His policies have increasingly left debris strewn across the world stage of trade and foreign policy. Sowing only chaos 
and confusion, there has been no rational balancing of economic and strategic interests. He has moved from being a disrupter to a destroyer of sound policies and institutions. However, the Supreme Court generally has restricted broader claims of presidential authority recently, and specialized trade courts are just beginning to restrict the president's actions. Although this cannot be seen as a great step forward, it is at least a meaningful start.

Congress unfortunately has done almost nothing to regain its trade powers, but it has stopped attempts to force the US withdrawal from the WTO, ${ }^{30}$ which, by the way, might well be on the table again if President Trump wins the forthcoming election.

Either the 2020 presidential election will put a stop to this irresponsible presidential reliance on national security to establish disastrous trade policies, or the country will be in this mess for years to come, probably even longer, which I hope not. However, the courts may still play a redemptive role. I hope so.

\section{REFERENCES}

1. Trump v. Vance (Decided July 9, 2020) (concerning criminal subpoenas issued by Manhattan District Attorney for President Trump's financial records held by his personal accounting firm), available at https://www.scotusblog.com/wp-content/uploads/2020/07/19-635_o7jq. pdf. See also Trump v. Mazars (Decided July 9, 2020) (concerning subpoenas issued by committees of the House of Representatives for President Trump's financial records held by Deutsche Bank), available at https://www.supremecourt.gov/opinions/19pdf/19-715_febh. pdf.

2. A. Liptak, Supreme Court Rules Trump Cannot Block Release of Financial Records, N.Y. Times, July 9, 2020, available at https://www.nytimes.com/2020/07/09/us/trump-taxessupreme-court.html.

3. See generally, A. Liptak, In a Term of Major Cases, the Supreme Court Tacked to the Center, N.Y. Times, July 10, 2020, available at https://www.nytimes.com/2020/07/10/us/ supreme-court-term.html?searchResultPosition=68.

4. Transpacific Steel v. United States (Slip Opinion 20-98) (Decided July 14, 2020), available at https://www.cit.uscourts.gov/sites/cit/files/20-98.pdf.

5. Id. at 22 .

6. American Institute for International Steel v. United States (U.S. Court of Appeals for the 
Federal Circuit) (Case No. 19-1727) (Decided Feb. 28, 2020), available at http://www.cafc. uscourts.gov/sites/default/files/opinions-orders/19-1727.Opinion.2-28-2020_1542185.pdf.

7. Transpacific Steel v. United States (United States Court of International Trade) (Slip Op 20-98) (Decided July 14, 2020), available at https://www.cit.uscourts.gov/sites/cit/ files/20-98.pdf.

8. Id. at 17.

9. Id. at 8 .

10. Federal Energy Administration v. Algonquin SNG, Inc. 426 U.S. 548, 559 (1976), available at $\mathrm{https}$ ://www.law.cornell.edu/supremecourt/text/426/548.

11. Trump v. Hawaii 138 S. Ct. 2392 (2018) (upholding President Trump's travel ban), available at $\mathrm{https} / / \mathrm{www}$.law.cornell.edu/supremecourt/text/17-965.

12. Transpacific Steel v. United States, supra note 7, at 17. [Emphasis added]

13. Id. at 18 .

14. Order List (\#19-1177) (June 22, 2020) (certiorari denied), available at https://www. supremecourt.gov/orders/courtorders/062220zor_mjn0.pdf.

15. Federal Energy Administration v. Algonquin SNG, Inc. 426 U.S. 548, 559 (1976), available at https://www.law.cornell.edu/supremecourt/text/426/548.

16. American Institute of international Steel v. United States (United States Court of International Trade) (Slip Opinion 19-37) (Decided March 25, 2019), available at https:// www.cit.uscourts.gov/sites/cit/files/19-37.pdf.

17. Judge Gary Katzman stated, "If the delegation permitted by section 232, as now revealed, does not constitute excessive delegation in violation of the Constitution, what would?" See id. at 28.

18. Executive Order on Addressing the Threat Posed by TikTok (Issued August 6, 2020), available at https://www.whitehouse.gov/presidential-actions/executive-orderaddressing-threat-posed-tiktok.

19. Executive Order on Addressing the Threat Posed by WeChat (Issued August 6, 2020), available at https://www.whitehouse.gov/presidential-actions/executive-orderaddressing-threat-posed-wechat.

20. International Emergency Economic Powers Act. 50 U.S.C. $\S 1701$, available at https:// www.law.cornell.edu/uscode/text/50/chapter-35.

21. National Emergencies Act. 50 USC 1601, available at https://www.law.cornell.edu/ uscode/text/50/chapter-34.

22. D. Michaela, White House Seeks Crackdown on U.S.-Listed Chinese Firms, Wall ST. J., Aug. 6, 2020, available at https://www.wsj.com/articles/trump-administration-seekscrackdown-on-chinese-companies-with-shares-traded-in-u-s-11596748284.

23. This includes newer US Treasury Department sanctions on Chinese officials over Beijing's declaration of a new national security law that the administration considers a violation of human rights in Hong Kong. See D. Nakamura, Once Reluctant to Hit China 
on Human Rights Trump Moves to Use the Issue as a Cudgel Amid Growing Tensions, WAsh. Post, Aug. 10, 2010, available at https://www.washingtonpost.com/politics/ trump-china-human-rights/2020/08/08/b2d09172-d97b-11ea-930e-d88518c57dcc_story. html.

24. S. Malawer, Trump, Litigation and Threats: From Queens to the World Stage, 6 CHINA \& WTO Rev. 210 (2020), available at http://cwr.yiil.org/home/pdf/archives/2020v6n1/cwr_ v6n1_08.pdf.

25. J. Bolton, The Room Where It Happened (2020).

26. $I d$. at 68 .

27. Id. at 290 .

28. Id. at $287 \& 289$.

29. C. Brown, There is Little Dignity in Trump's Trade Policy, Foreign AfF., July 9, 2020, available at https://www.foreignaffairs.com/articles/united-states/2020-07-09/there-littledignity-trumps-trade-policy.

30. D. Palmer, New Ruling Quashes Hawley's Hope for Senate WTO Withdrawal Vote, Politico, July 1, 2020, available at https://www.politico.com/news/2020/07/01/rulingquashes-hawley-hope-senate-wto-withdrawal-347732. 
